International Journal of Current Microbiology and Applied Sciences

ISSN: 2319-7706 Volume 10 Number 10 (2021)

Journal homepage: http://www.ijcmas.com

Review Article

https://doi.org/10.20546/ijcmas.2021.1010.064

\title{
Contrast Enhanced Ultrasound: An Overview
}

\author{
Neelam Tandia ${ }^{1 *}$, Anuradha Nema ${ }^{1}$, Swatantra K. Singh ${ }^{2}$, \\ Kavita Rawat ${ }^{3}$ and Rajesh Vandre ${ }^{4}$
}

\author{
${ }^{1}$ Department of Veterinary Surgery and Radiology, ${ }^{2}$ Department of Veterinary Pharmacology \\ and Toxicology, ${ }^{3}$ Department of Veterinary Physiology and Biochemistry, ${ }^{4}$ Department of \\ Veterinary Genetics and Breeding, College of Veterinary Science and AH, Rewa \\ *Corresponding author
}

\section{A B S T R A C T}

Keywords

Contrast-enhanced ultrasound, microbubbles, nanobubbles, tissue perfusion

Article Info

Accepted:

18 September 2021 Available Online: 10 October 2021
Application of ultrasound contrast medium to traditional medical sonography is known as Contrast-enhanced ultrasound (CEUS) that enhances contrast during ultrasnography by increasing ultrasound backscatter (reflection) of the ultrasound waves. Contrast-enhanced ultrasound can be used in diagnostic imaging, organ edge delineation, echocardiography, blood volume perfusion, lesion characterization, drug or gene delivery, molecular imaging etc. Different types of contrast media used in ultrasonography are agitated saline, microbubbles, nanobubbles etc. Adverse reactions of contrast agent include headache, hypersensitivity abdominal pain, diarrhoea, dyspepsia, hypertension, leg cramps etc. Although CEUS is popular now a days but with certain limitations such as more heat production with increase in frequency, short life of microbubbles, continuous monitoring, occasional microvasculature rupture and haemolysis. In conclusion, CEUS is an advanced technique for absolute quantification of tissue perfusion, drugs and genes delivery, differential diagnosis and monitoring therapy response.

\section{Introduction}

Contrast-enhanced ultrasound (CEUS) is the application of ultrasound contrast medium to traditional medical sonography. Ultrasound contrast agents rely on the different ways in which sound waves are reflected from interfaces between substances. This may be the surface of a small air bubble or a more complex structure (https://en.wikipedia.org/ wiki/Contrast-enhanced_ultrasound).

Commercially available contrast media are gas-filled microbubbles that are administered 
intravenously to the systemic circulation. Microbubbles have a high degree of echogenicity (the ability of an object to reflect ultrasound waves). There is a great difference in echogenicity between the gas in the microbubble and the soft tissue surroundings of body. Thus, ultrasonic imaging using microbubble contrast agents enhances the ultrasound backscatter (reflection) of the ultrasound waves, to produce a sonogram with increased contrast due to high echogenicity difference. Contrast-enhanced ultrasound can be used to image blood perfusion in organs, measure blood flow rate in heart and other organs and for other applications. CEUS is an option and was shown to improve cancer detection and tumor characterization, decreasing the number of biopsies, or during surgery in brain cancer patients (Kitano et al., 2012; Uemura et al., 2013; Prada et al., 2014).

\section{History}

Application of CEUS started in late 1960s when a detectable signal change during US examination was observed after injection of agitated saline caused (Kremkau et al., 1970). Contrast enhancement by the compressible gas core of saline bubbles was caused by backscatter of US wave. But, due to the high surface tension saline bubbles were unstable. Kremkau et al., 1970 formed more stable bubbles by injection of autologous blood at adequately rapid rates. Nonetheless, bubbles still lacked sufficient lifetime and a defined size. After more than 20 years first stable commercially available and FDA approved USCA- Albunex, an albumin-coated and airfilled microsphere was found (Feinstein et al., 1990).

Since then, stability and biocompatibility of USCA have been continuously improved and bubbles have been modified to specifically target certain surface molecules expressed in pathological alterations. Apart from their support for imaging and diagnostics, microand NBs are object of increased interest for therapeutic applications too. Recent studies used the disrupting effect of MB-enhanced US on the BBB in combination with transplantation of mesenchymal stem cells for treatment of brain ischemia, or used MBs as carriers of drugs, siRNA and mRNA (Dewitte et al., 2014; Gong et al., 2014). This broad field of different uses makes USCA attractive for research and beneficial for patients.

Currently three different MB-based CA are clinically approved in the United States/North America and Europe, and a fourth is clinically used in Japan and South Korea, but the variety among the investigative $\mathrm{CA}$ is much broader and frequently produces new, promising progenies. Since examinations with those approved $\mathrm{CA}$ are common in the clinics, guidelines for CEUS imaging of the liver exist to guarantee proper and comparable examinations and an improvement for diagnosis and therapy (Claudon et al., 2013).

\section{Principle of CEUS}

US contrast agents consist of microbubbles containing air or various gases within a shell. When a US contrast agent is administered into the vasculature, it enhances the backscatter of ultrasound waves by resonance within sonic windows (Sontum, 2008). This results in a marked amplification of the signals from the blood flow and provides additional information about the microvasculature (Gries, 2004).

\section{Types of contrast media}

\section{First generation}

First-generation ultrasound contrast agents contained microbubbles of air that were dissolved in blood when exposed to acoustic pressure in the ultrasound field. They were 
therefore present in the bloodstream for a limited time.

\section{Second generation}

Second-generation contrast agents include microbubbles of perfluorocarbon, nitrogen gas or sulfur hexafluoride stabilized in a phospholipid membrane. When exposed to the ultrasound beam, bubbles oscillate (they are being compressed by the effect of positive pressure created by the ultrasound waves and they expand in the negative pressure phase). The compression of the gas is greater than expansion which creates a non-linear response (echo). This greatly affects ultrasound backscatter and increases vascular contrast in a similar manner to intravenous contrast media used in CT and MRI (Balint Botz et al.,)

\section{Microbubble}

As the name suggests, the diameter ranges between 1 and $10 \mu \mathrm{m}$. This size normally limits the application of $\mathrm{MB}$ to the intravascular system to assess functional parameters like vascularity, perfusion, blood flow velocity, angiogenicity or to characterize vasculature molecularly by using targeted MB (Yuan and Rychak, 2013). Hence, shell was introduced to produce soft- and hard-shell bubbles, that provide multiple specific applications of $\mathrm{MB}$ by changing their viscoelastic properties (Hoff et al., 1996; Kiessling et al., 2014). To rule out possible changes in bubble-size by air diffusing along the concentration gradient between blood and bubble, $\mathrm{MB}$ is produced with a defined mixture of PFC and air, so that Laplace and arterial pressure are in equilibrium (Schutt et al., 1996).

MBs of a diameter below the maximum of 10 $\mu \mathrm{m}$ were obtainable and for certain mixtures a shelf time of several weeks and a high echogenicity in B-mode US imaging were shown (Singhal et al., 1993; Wheatley et al., 1994). Still, those MB that succeeded in clinical trials were of different materials. Imagent $^{\circledR}$ (IMCOR Pharmaceuticals Inc., San Diego, CA, USA) MB of approximately $5 \mu \mathrm{m}$ in diameter, filled with a mixture of air and PFCs, were first tested for renal and liver perfusion studies in rabbits, later for myocardial perfusion and detection of general blood flow abnormalities using Doppler US. It showed promising contrast and compatibility with almost no adverse side effects in first clinical trials (Taylor et al., 1996; Sirlin et al., 1997; Pelura, 1998).

\section{Different types of microbubbles used in ultrasonography are}

\section{Polymer-shelled microbubbles}

First polymers used for US applications were naturally occurring air-filled polymers. Gelatin was among the first biopolymers to be tested, but the production of adequately small MB turned out to be difficult and their circulation time was short (Carroll et al., 1980). Cyanoacrylate polymers were first used as a shell material by Fritzsch et al., (1994).

\section{Hard-shell microbubbles}

They mainly consists of gas bubbles with a coating of lower visco-elastical properties such as polymers or denatured proteins, as well as porous silica materials encapsulating gas.

\section{Protein-shelled microbubbles}

Though protein-shelled microbubbles are less resistant to US waves than polymer-coated $\mathrm{MB}$, but with a longer history of use and development, the first commercially available USCA was the protein-shelled MB Albunex ${ }^{\circledR}$ (Molecular Biosystems, San Diego, CA, USA). 
First animal experiments showed an enhanced contrast in 2D echocardiography after intravenous injection (Keller et al., 1987) and a behavior similar to erythrocytes to guarantee no interferences in coronary flow or hemodynamics caused by the CA during myocardial US examination (Keller et al., 1988, 1989).

\section{Soft-shell microbubbles}

Soft-shell MBs are commonly used for examinations using a low mechanical index (MI) since these MB are sensitively detectable by their non-linear oscillations. The better oscillation properties of SS-MB compared with HS-MB are due to the thinner, more flexible shells, which are held together not by covalent bonding, but hydrophobic interactions. Therefore, after slight shell disruptions, the shell seals itself to minimize surface tension (Borden et al., 2005; Brismar et al., 2012). Most common shell materials for SS-MB are surfactant molecules or phospholipids, where the length of the acyl chain mainly influences the bubbles' acoustic dissolution and the monolayers' cohesiveness (Borden et al., 2005).

\section{Phospholipid microbubbles}

The first lipid-based USCA that made it to clinical trials and the clinics was Perflutren, sold as Definity or Luminity (Lantheus Medical Imaging, North Billerica, MA, USA). It contains perfluoropropane-filled $\mathrm{MB}$ in a shell made of three different saturated 16carbon-long phospholipids. With an average size between only $1-2 \mu \mathrm{m}$ they are smaller than most HS-MB (Unger et al., 2004). Similar to HS-MB, lipid-based MBs have been found to be useful for therapeutic applications. They have also been successfully tested for thrombolysis in combination with US and thrombolytic agents (Unger et al., 2004). Apart from Definity ${ }^{\circledR} /$ Luminity $^{\circledR}$, another SS-MB has clinical approval for cardiologic applications. SonoVue ${ }^{\circledR}$ (Bracco Imaging) gained FDA-approval in 2001 but was withdrawn, and again in 2014, came under the name Lumason ${ }^{\circledR}$. This sulfur hexafluoride filled phospholipid-MB are generally used for left ventricular opafication and endocardial border definition, but in some countries also have approval for general vessel diagnostic or imaging of microvascular structures in the breast or differentiation of lesions in the liver (Claudon et al., 2013; Appis et al., 2015). Apart from that, SonoVue ${ }^{\circledR}$ has also been tested in clinical trials for monitoring of uterine fibroid vascularization and improved ablation (Henri et al., 2014; Jiang et al., 2014).

\section{Surfactant-stabilized microbubbles}

After the mid-90s usage of surfactantstabilized gaseous MB for US diagnostics was suggested by Hilmann et al., (1985).

\section{Nanobubbles}

In certain conditions, MBs, due to their size are unable to leave the vasculature, even in solid tumors, which often have leaky vasculature and a poor lymphatic drainage. This leads to extravasation and retention of macromolecules, also known as the EPR effect (enhanced permeability and retention). To extravasate to the tumor itself, bubbles need to be smaller than $400-800 \mathrm{~nm}$ in diameter, and are referred to as NBs. It has been shown that even bubbles of this dimension were able to produce an enhanced backscatter after US application (Oeffinger and Wheatley, 2004). 
Table.1 Ultrasound contrast agent that had been clinically approved

\begin{tabular}{|c|c|c|c|c|c|c|}
\hline Name & $\begin{array}{l}\text { First approved } \\
\text { for clinical use }\end{array}$ & Shell material & Gas & Application (examples) & Producer/distributor & Countries \\
\hline Optison & 1998 & $\begin{array}{l}\text { Cross-linked } \\
\text { serum albumin }\end{array}$ & Octafluoropropane & Left ventricular opafication & $\begin{array}{l}\text { GE healthcare, } \\
\text { Buckinghamshire, UK }\end{array}$ & US, Europe \\
\hline Sonazoid & 2007 & Phospholipid & Perfluorobutane & $\begin{array}{l}\text { Myocardial perfusion, liver } \\
\text { imaging }\end{array}$ & $\begin{array}{l}\text { GE healthcare, } \\
\text { Buckinghamshire, UKJ } \\
\text { Daiichi Saniko, Tokyo, JP }\end{array}$ & $\begin{array}{l}\text { Japan, South } \\
\text { Korea }\end{array}$ \\
\hline Lumason/SonoVue & $2001 / 2014$ & Phospholipid & Sulphurhexafluoride & $\begin{array}{l}\text { Left ventricular } \\
\text { opafication, microvascular } \\
\text { enhancement (liver and } \\
\text { breast lesion detection) }\end{array}$ & $\begin{array}{l}\text { Bracco diagnostics, } \\
\text { Milano, Italy }\end{array}$ & $\begin{array}{l}\text { US, Europe, } \\
\text { China }\end{array}$ \\
\hline Definity/Luminity & $2001 / 2006$ & Phospholipid & Octafluoropropane & $\begin{array}{l}\text { Echocardiography, } \\
\text { liver/kidney imaging } \\
\text { (Canada) }\end{array}$ & $\begin{array}{l}\text { Lantheus medical } \\
\text { Imaging, North Billerica, } \\
\text { MA }\end{array}$ & $\begin{array}{l}\text { North America, } \\
\text { Europe (approval } \\
\text { fled) }\end{array}$ \\
\hline Imagent/mavist & 2002, withdrawn & Phospholipid & $\begin{array}{l}\text { Perfluorohexane, } \\
\text { Nitrogen }\end{array}$ & $\begin{array}{l}\text { Echocardiography, heart } \\
\text { perfusion, tumor/blood } \\
\text { flow anomalies }\end{array}$ & Schering AG, Berlin, DE & US \\
\hline Echovist & 1991, withdrawn & $\begin{array}{l}\text { Galactose } \\
\text { microparticles }\end{array}$ & Air & Right heart imaging & Schering AG, Berlin, DE & Germany, UK \\
\hline Levovist & 1995, withdrawn & $\begin{array}{l}\text { Galactose } \\
\text { microparticles, } \\
\text { palmitic acid }\end{array}$ & Air & $\begin{array}{l}\text { Whole heart imaging, } \\
\text { doppler imaging }\end{array}$ & Schering AG, Berlin, DE & $\begin{array}{l}\text { Canada, Europe, } \\
\text { China, Japan }\end{array}$ \\
\hline Albunex & 1993, withdrawn & $\begin{array}{l}\text { Sonicated } \\
\text { serum albumin }\end{array}$ & air & Transpulmonary imaging & $\begin{array}{l}\text { Molecular Biosystems } \\
\text { Inc., San Diego, CA, USA }\end{array}$ & Japan, US \\
\hline
\end{tabular}


Table.2 Microbubbles and their target receptors

\begin{tabular}{|c|c|c|c|c|}
\hline Microbubbles & Target tissue & Receptor & Ligand & Outcome \\
\hline $\begin{array}{c}\text { Perfluorobutane, lipid } \\
\text { derived MB }\end{array}$ & $\begin{array}{l}\text { Coronary } \\
\text { artery } \\
\text { endothelial } \\
\text { cells }\end{array}$ & ICAM-1 & $\begin{array}{l}\text { Monoclonal } \\
\text { antibody to } \\
\text { ICAM-1 }\end{array}$ & $\begin{array}{c}\text { Significantly } \\
\text { increased } \\
\text { binding of MB } \\
\text { with anti-ICAM- } \\
1\end{array}$ \\
\hline $\begin{array}{l}\text { Lipid-coated } \\
\text { perfluorocarbon } \\
\text { containing MB }\end{array}$ & Thrombus & $\begin{array}{l}\text { GPIIbIIIa- } \\
\text { receptor }\end{array}$ & $\begin{array}{l}\text { Bioconjugate } \\
\text { ligands }\end{array}$ & $\begin{array}{l}\text { Higher affinity } \\
\text { of targeted MB } \\
\text { versus } \\
\text { untargeted MB }\end{array}$ \\
\hline $\begin{array}{l}\text { Lipid MB containing } \\
\text { decafluorobutane }\end{array}$ & $\begin{array}{l}\text { Inflamed } \\
\text { tissue }\end{array}$ & $\begin{array}{l}\text { Complement- } \\
\text { mediated } \\
\text { attachment to } \\
\text { leucocytes }\end{array}$ & PS & $\begin{array}{c}\text { Greater } \\
\text { attachment of PS } \\
\text { containing } \\
\text { bubbles }\end{array}$ \\
\hline $\begin{array}{l}\text { Perfluorobutane } \\
\text { containing MB }\end{array}$ & $\begin{array}{l}\text { Avidin coated } \\
\text { culture plates }\end{array}$ & Avidin & Biotin & $\begin{array}{l}\text { Increased } \\
\text { attachment in } \\
\text { contrast to } \\
\text { control MB }\end{array}$ \\
\hline
\end{tabular}

Table.3 Adverse reactions of contrast agent

\begin{tabular}{|c|c|c|}
\hline Adverse event & $\begin{array}{l}\text { Frequency } \\
0.5-5 \%\end{array}$ & Frequency $<1 \%$ \\
\hline Systemic & Headache, Hypersensitivity & $\begin{array}{l}\text { Abdominal pain, weakness, } \\
\text { chest pain }\end{array}$ \\
\hline Cardiovascular & Hypertension & $\begin{array}{l}\text { Arterial fibrillation, palpitation } \\
\text { and tachycardia }\end{array}$ \\
\hline Digestive System & Nausea & Anorexia, diarrhoea, dyspepsia \\
\hline CNS & Dizziness, Dry mouth, Vasodialation & Leg cramps, paresthesia \\
\hline Respiratory, Skin & & $\begin{array}{l}\text { Dyspnoea, Sweating, rash and } \\
\text { pruritis }\end{array}$ \\
\hline Special Senses & Altered taste and smell & \\
\hline
\end{tabular}


Fig.1 Microbubble constructed for drug delivery. A stabilising material, here a lipid, surrounds the perfluorocarbon bubble. Drugs may be incorporated by themselves or, if insoluble in water,

in an oil layer ( Martin J K Blomley). The microsphere may be targeted to specific tissue by incorporating protein ligands on the surface.

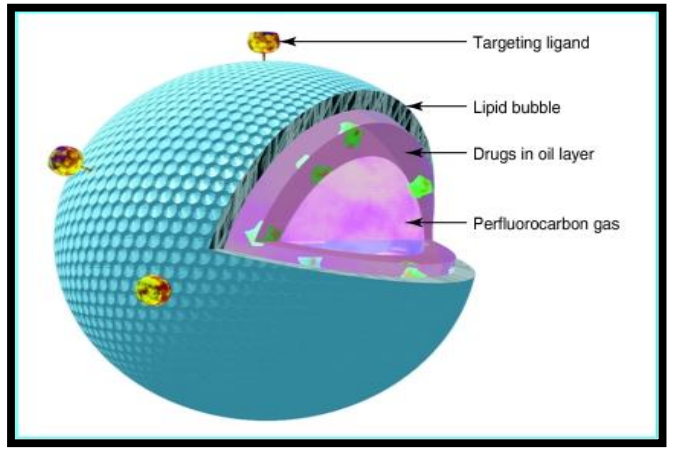

\section{Application of CEUS}

Diagnostic imaging, medical application, organ edge delineation, echocardiography, blood volume perfusion and lesion characterization are certain applications of CEUS and are as follows.

\section{Sentinel lymph node (SLN) detection}

Lymphosonography, or CEUS-guided SLN detection, as a technique for demonstrating lymphatic drainage, has been introduced in some experimental studies. In this procedure, transcutaneous injection of an UCA is performed and CEUS is used to identify draining lymphatic channels and SLNs. This use of CEUS is technically feasible, as was demonstrated by various studies (Curry et al., 2009, Wang et al., 2009).

\section{Drug or gene delivery}

The microbubble contrast agent interacts with the acoustic wave in the acoustic field. The contrast agent itself will serve as a cavitation nucleus and lower the threshold level for cavitation (Wang et al., 2008, Nie, et al., 2006). In an experimental study, Nie et al., (2008) found that compared with the group treated by US alone, KDR-tk gene therapy

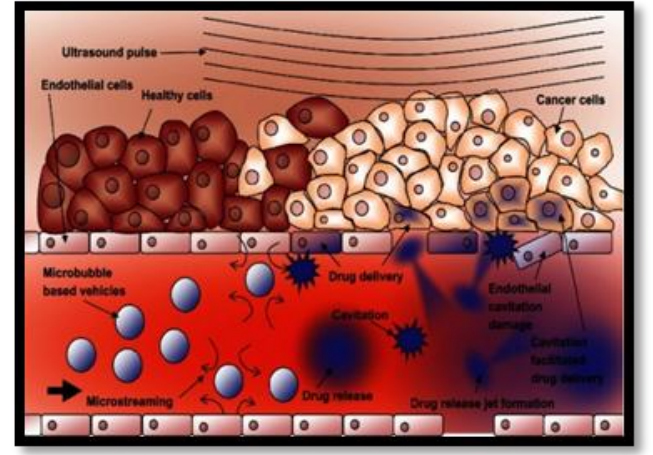

treated by US combined with SonoVue inhibited tumour growth and increased survival time of Hepa1-6 tumour-bearing mice. It was concluded that gene therapy mediated by US exposure enhanced by a microbubble contrast agent may become a new treatment option for HCC.

Based on the same principle, UCA was used for drug delivery in the treatment of acute intravascular thrombi by Wang, et al., (2010) and Xie, et al., (2009).

\section{Molecular imaging}

Techniques for non invasive imaging of specific disease-related molecular changes are being developed to enhance diagnosis and therapeutic decision-making. Molecular imaging with CEUS relies on the detection of the acoustic signal produced by microbubble or nanoparticle agents that are targeted to the sites of disease. The potential use of CEUSbased molecular imaging in atherosclerosis, post-ischemic inflammation, angiogenesis, transplant rejection and thrombus formation have been investigated, and is undoubtedly an important development trend (Linder, 2009, Kaufmann, et al., 2007, Bohman, et al., 2009, Leong Poi, et al., 2007 and Lankford, et al., 2006). 


\section{Commercially available contrast agents}

There are different types of contrast agents which are available in the market like simple air (Nitrogen), perfluorocarbon and sulfur hexachloride preparations (Vera Paefgen et al., 2015) Table.1.

\section{Procedure for CEUS}

After preparation the target organ is focused on B-mode US and then contrast-specific imaging mode is turned on. On ultrasound after the contrast is administered, the tissue is divided on basis of perfussion i.e. hyperenhancing, isoenhancing, hypoenhancing.

\section{Limitations of technique}

Different limitations regarding contrast enhanced ultrasound are ultrasound produces more heat as the frequency increases, Microbubbles don't last very long in circulation, Continues monitoring is required, Microbubbles burst at low ultrasound frequencies and may cause local microvasculature rupture and haemolysis and Costly with time consuming. Contrast enhanced ultrasound helps in different aspect likewise in absolute quantification of tissue perfusion, Helps in drugs and genes delivery, Lower intravenous dosage is needed, Guided organ transplantation, Localization of lesion, Helpful for the differential diagnosis, Differentiation between malignant \& benign tumour and Monitoring response of tumor therapy.

\section{Abbreviation}

CEUS - Contrast enhanced ultrasound

MB - Microbubble

NB - Nanobubble

USCA - Ultrasound contrast agent

BBB - Blood brain barrier

\section{References}

Appis, A. W., Tracy, M. J., and Feinstein, S. B. (2015). Update on the safety and efficacy of commercial ultrasound contrast agents in cardiac applications. Echo Res. Pract. 2, R55-R62. doi: 10.1530/ERP-15-0018

Balint Botz ${ }^{\circ}$ and Marcin Czarniecki et al., Contrast-enhanced ultrasound https://radiopaedia.org/

Böhmer M R, Klibanov A L, Tiemann K, Hall C S, Gruell H, Steinbach O C. Ultrasound triggered image-guided drug delivery. Eur J Radiol. 2009;70:242-253. [PubMed] [Google Scholar]

Borden, M. A., Kruse, D. E., Caskey, C. F., Zhao, S., Dayton, P. A., and Ferrara, K. W. (2005). Influence of lipid shell physicochemical properties on ultrasoundinduced microbubble destruction. IEEE Trans. Ultrason. Ferroelectr. Freq. Control 52, 1992-2002. doi: 10.1109/TUFFC.2005.1561668

Brismar, T. B., Grishenkov, D., Gustafsson, B., Härmark, J., Barrefelt, ̊., Kothapalli, S. V. V. N., et al., (2012). Magnetite nanoparticles can be coupled to microbubbles to support multimodal imaging. Biomacromolecules 13, 13901399. doi: 10.1021/bm300099f

Carroll, B. A., Turner, R. J., Tickner, E. G., Boyle, D. B., and Young, S. W. (1980). Gelatin encapsulated nitrogen microbubbles as ultrasonic contrast agents. Invest. Radiol. 15, 260-266. doi: 10.1097/00004424-198005000198005013

Claudon M., Dietrich C. F., Choi B. I., Cosgrove D. O., Kudo M., Nolsøe C. P., et al., (2013). Guidelines and good clinical practice recommendations for contrast enhanced ultrasound (CEUS) in the Liver - Update 2012. A WFUMB-EFSUMB Initiative in Cooperation with Representatives of AFSUMB, AIUM, ASUM, FLAUS and ICUS. Ultrasound Med. Biol. 39 187-210

Claudon, M., Dietrich, C. F., Choi, B. I., 
Cosgrove, D. O., Kudo, M., Nolsøe, C. P., et al., (2013). Guidelines and good clinical practice recommendations for contrast enhanced ultrasound (CEUS) in the Liver - Update 2012. A WFUMB-EFSUMB Initiative in Cooperation with Representatives of AFSUMB, AIUM, ASUM, FLAUS and ICUS. Ultrasound Med. Biol. 39, 187-210. doi: 10.1016/j.ultrasmedbio.2012.09.002

Curry J M, Ezzat W H, Merton D A, Goldberg B B, Cognetti D M, Rosen D, Pribitkin E A. Thyroid lymphosonography: a novel method for evaluating lymphatic drainage. Ann Otol Rhinol Laryngol. 2009;118:645-650. [PubMed] [Google Scholar]

Dewitte H., Van Lint S., Heirman C., Thielemans K., De Smedt S. C., Breckpot K., et al., (2014). The potential of antigen and TriMix sonoporation using mRNAloaded microbubbles for ultrasoundtriggered cancer immunotherapy. $J$. Control. Release Submitted 194 28-36. 10.1016/j.jconrel.2014.08.011 [PubMed] [CrossRef] [Google Scholar]

Feinstein S. B., Cheirif J., Ten Cate F. J., Silverman P. R., Heidenreich P. A., Dick C., et al., (1990). Safety and efficacy of a new transpulmonary ultrasound contrast agent: initial multicenter clinical results. $J$. Am. Coll. Cardiol. $16 \quad 316-324$. 10.1016/0735-1097(90)90580-I [PubMed] [CrossRef] [Google Scholar]

Fritzsch, T., Hauff, P., Heldmann, F., Lüders, F., Uhlendorf, V., and Weitschies, W. (1994). Preliminary results with a new liver specific ultrasound contrast agent. Ultrasound. Med. Biol. 20, S137.

Gong Z., Ran H., Wu S., Zhu J., Zheng J. (2014). Ultrasound-microbubble transplantation of bone marrow stromal cells improves neurological function after forebrain ischemia in adult mice. Cell Biochem. Biophys. 70 499-504. 10.1007/s 12013-014-9947-y [PubMed] [CrossRef] [Google Scholar

Gramiak R., Shah P. M. (1968). Echocardiography of the Aortic Root.
Invest. $\quad$ Radiol. 3 301-388. 10.1097/00004424-196809000-00011

[CrossRef] [Google Scholar]

Greis C. Technology overview: SonoVue (Bracco, Milan) Eur Radiol. 2004;14 Suppl 8:P11-P15. [PubMed] [Google Scholar]

Henri, M., Florence, E., Aurore, B., Denis, H., Frederic, P., Francois, T., et al., (2014). Contribution of contrast-enhanced ultrasound with Sonovue to describe the microvascularization of uterine fibroid tumors before and after uterine artery embolization. Eur. J. Obstet. Gynecol. Reprod. Biol. 181, 104-110. doi: 10.1016/j.ejogrb.2014.07.030

Hilmann, J., Hoffmann, R. R., Muetzel, W., and Zimmermann, I. (1985). Carrier liquid solutions for the production of gas microbubbles, preparation thereof, and use thereof as contrast medium for ultrasonic diagnostics. Ultrasound Med. Biol. US Patent 4466442: 11, II.

Hoff, L., Sontum, P. C., and Hoff, B. (1996). Acoustic properties of shell-encapsulated, gas-filled ultrasound contrast agents. Proc. IEEE Ultrason. Symp. 2, 14411444.

doi: 10.1109/ULTSYM.1996.584337

Jiang, N., Xie, B., Zhang, X., He, M., Li, K., Bai, J., et al., (2014). Enhancing ablation effects of a microbubble-enhancing contrast agent ("sonovue") in the treatment of uterine fibroids with highintensity focused ultrasound: a randomized controlled trial. Cardiovasc. Intervent. Radiol. 37, 1321-1328. doi: 10.1007/s00270-013-0803-z

Kaufmann B A, Sanders J M, Davis C, Xie A, Aldred P, Sarembock I J, Lindner J R. Molecular imaging of inflammation in atherosclerosis with targeted ultrasound detection of vascular cell adhesion molecule-1. Circulation. 2007;116:276284. [PubMed] [Google Scholar]

Keller, M. W., Feinstein, S. B., and Watson, D. D. (1987). Successful left ventricular opacification following peripheral venous injection of sonicated contrast agent: an 
experimental evaluation. Am. Heart J. 114, 570-575. doi: 10.1016/00028703(87)90754-X

Keller, M. W., Glasheen, W., Teja, K., Gear, A., and Kaul, S. (1988). Myocardial contrast echocardiography without significant hemodynamic effects or reactive hyperemia: a major advantage in the imaging of regional myocardial perfusion. J. Am. Coll. Cardiol. 12, 1039-1047. doi: 10.1016/0735-1097(88)90474

Keller, M. W., Segal, S. S., Kaul, S., and Duling, B. (1989). The behavior of sonicated albumin microbubbles within the microcirculation: a basis for their use during myocardial contrast echocardiography. Circ. Res. 65, 458-467. doi: 10.1161/01.RES.65.2.458

Kiessling, F., Mertens, M. E., Grimm, J., and Lammers, T. (2014). Nanoparticles for imaging: top or flop? Radiology 273, 1028. doi: $10.1148 /$ radiol.14131520

Kitano M., Kudo M., Yamao K., Takagi T., Sakamoto H., Komaki T., et al., (2012). Characterization of small solid tumours in the pancreas: the value of contrastenhanced harmonic endoscopic ultrasonography. Am. J. Gastroenterol. 107 303-310. 10.1038/ajg.2011.354 [PubMed] [CrossRef] [Google Scholar]

Kremkau F. W., Gramiak R., Carstensen E. L., Shah P. M., Kramer D. H. (1970). Ultrasonic detection of cavitation at catheter tips. Am. J. Roentgenol. $110177-$ 183. 10.2214/ajr.110.1.177 [PubMed] [CrossRef] [Google Scholar]

Lankford M, Behm C Z, Yeh J, Klibanov A L, Robinson $\mathrm{P}$, Lindner $\mathrm{J} \mathrm{R}$. Effect of microbubble ligation to cells on ultrasound signal enhancement: implications for targeted imaging. Invest Radiol. 2006;41:721-728. [PubMed] [Google Scholar]

Leong-Poi H, Kuliszewski M A, Lekas M, Sibbald M, Teichert-Kuliszewska K, Klibanov A L, Stewart D J, Lindner J R. Therapeutic arteriogenesis by ultrasoundmediated VEGF165 plasmid gene delivery to chronically ischemic skeletal muscle.
Circ Res. 2007;101:295-303. [PubMed] [Google Scholar]

Lindner J R. Molecular imaging of cardiovascular disease with contrastenhanced ultrasonography. Nat Rev Cardiol. 2009;6:475-481. [PubMed] [Google Scholar]

Nie F, Xu H X, Lu M D, Wang Y, Tang Q. Anti-angiogenic gene therapy for hepatocellular carcinoma mediated by microbubble-enhanced ultrasound exposure: an in vivo experimental study. $\mathbf{J}$ Drug Target. 2008;16:389-395. [PubMed] [Google Scholar]

Nie F, Xu HX, Tang Q, Lu M D. Microbubbleenhanced ultrasound exposure improves gene transfer in vascular endothelial cells. World J Gastroenterol. 2006;12:75087513. [PMC free article] [PubMed] [Google Scholar]

Oeffinger, B. E., and Wheatley, M. A. (2004). Development and characterization of a nano-scale contrast agent. Ultrasonics 42 , 343-347.

doi: 10.1016/j.ultras.2003.11.011

Pelura, T. J. (1998). Clinical experience with AF0150 (Imagent US), a new ultrasound contrast agent. Acad. Radiol. 5, S69-S71. doi: $\quad$ 10.1016/S1076-6332(98)8006480060

Prada F., Perin A., Martegani A., Aiani L., Solbiati L., Lamperti M., et al., (2014). Intraoperative contrast-enhanced ultrasound for brain tumor surgery. Neurosurgery $74 \quad 542-552$. 10.1227/NEU.0000000000000301

[PubMed] [CrossRef] [Google Scholar]

Schutt, E. G., Pelura, T. J., and Hopkins, R. M. (1996). Osmotically stabilized microbubble sonographic contrast agents. Acad. Radiol. 3(Suppl. 2), S188-S190. doi: $\quad$ 10.1016/S1076-6332(96)8053080537

Singhal, S., Moser, C. C., and Wheatley, M. A. (1993). Surfactant-stabilized microbubbles as ultrasound contrast agents: stability study of span-60 and tween-80 mixtures using a langmuir trough. Langmuir 9, 2426-2429. doi: 10.1021/la00033a027 
Sirlin, C. B., Girard, M. S., Steinbach, G. C., Baker, K. G., Broderdorf, S. K., Hall, L. A., et al., (1997). Effect of ultrasound transmit power on liver enhancement with Imagent US, a PFC-stabilized microbubble contrast agent. Int. J. Imaging Syst. Technol. 8, 82-88. doi: 10.1002/(SICI)1098-

1098(1997)8:1<82::AID-IMA10>3.0.CO 2-N

Sontum P C. Physicochemical characteristics of Sonazoid, a new contrast agent for ultrasound imaging. Ultrasound Med Biol. 2008;34:824-833. [PubMed] [Google Scholar]

Taylor, G. A., Ecklund, K., and Dunning, P. S. (1996). Renal cortical perfusion in rabbits: visualization with color amplitude imaging and an experimental microbubble-based US contrast agent. Radiology 201, 125-129. doi: 10.1148/radiology.201.1.8816532

Uemura H., Sano F., Nomiya A., Yamamoto T., Nakamura M., Miyoshi Y., et al., (2013). Usefulness of perflubutane microbubbleenhanced ultrasound in imaging and detection of prostate cancer: phase II multicenter clinical trial. World J. Urol. $31 \quad 1123-1128 . \quad 10.1007 / \mathrm{s} 00345-012-$ 0833-831 [PubMed] [CrossRef] [Google Scholar]

Unger, E. C., Porter, T., Culp, W., Labell, R., Matsunaga, T., and Zutshi, R. (2004). Therapeutic applications of lipid-coated microbubbles. Adv. Drug Deliv. Rev. 56, 1291-1314. doi: 10.1016/j.addr.2003.12.006

Vera P, Dennis D and Fabian K. Evolution of contrast agents for ultrasound imaging and ultrasound- mediated drug delivery: Front pharmacol. V6; 2015;6:197.

Wang Y, Cheng Z, Li J, Tang J. Gray-scale contrast-enhanced utrasonography in detecting sentinel lymph nodes: An animal study. Eur J Radiol. 2009:Epub ahead of print. [PubMed] [Google Scholar]

Wang Y, Li X, Zhou Y, Huang P, Xu Y. Preparation of nanobubbles for ultrasound imaging and intracelluar drug delivery. Int J Pharm. 2010;384:148-153. [PubMed] [Google Scholar]

Wang Y, Xu HX, Lu M D, Tang Q. Expression of thymidine kinase mediated by a novel non-viral delivery system under the control of vascular endothelial growth factor receptor 2 promoter selectively kills human umbilical vein endothelial cells. World J Gastroenterol. 2008;14:224-230. [PMC free article] [PubMed] [Google Scholar]

Wheatley, M. A., Peng, S., Singhal, S., and Goldberg, B. B. (1994). Surfactantstabilized microbubble mixtures, process for preparing and methods of using the same. US. Patent 5352436. https://en.wikipedia.org/wiki/Contrastenhanced_ultrasound,google.com.

Xie F, Lof J, Everbach C, He A, Bennett R M, Matsunaga T, Johanning J, Porter TR. Treatment of acute intravascular thrombi with diagnostic ultrasound and intravenous microbubbles. JACC Cardiovasc Imaging. 2009;2:511-518. [PubMed] [Google Scholar]

Yuan, B., and Rychak, J. (2013). Tumor functional and molecular imaging utilizing ultrasound and ultrasound-mediated optical techniques. Am. J. Pathol. 182, 305-311. doi: 10.1016/j.ajpath.2012.07.036.

\section{How to cite this article:}

Neelam Tandia, Anuradha Nema, Swatantra K. Singh, Kavita Rawat and Rajesh Vandre. 2021. Contrast Enhanced Ultrasound: An Overview. Int.J.Curr.Microbiol.App.Sci. 10(10): 539-549. doi: https://doi.org/10.20546/ijcmas.2021.1010.064 